\title{
5 The Wadden Sea: A natural landscape outside the dikes
}

\author{
Hans-Ulrich Rösner
}

\begin{abstract}
The Wadden Sea of today is largely a natural landscape, one of the last of its kind in Western Europe. This is the case because natural forces in the Wadden Sea are so strong that the area could not be transformed into a cultural landscape before the protection of nature became an important asset for our society about 40 years ago. Consequently, the guiding principle for the protection of the entire Wadden Sea area, which was decided upon by the three Wadden Sea countries as early as 1991, is 'to achieve, as far as possible, a natural and sustainable ecosystem in which natural processes proceed in an undisturbed way'. The protection of the Wadden Sea is strongly linked to this guiding principle, and this is also what the inscription of the Wadden Sea as a World Heritage Site in 2009 is based upon.

There is a rather clear spatial segregation between the natural landscape and the cultural landscape by the dikes, the cultural landscape usually being on the landward side. However, some of the cultural landscapes, e.g. old grasslands, are also very rich in natural values. Moreover, important cultural values can also be found within the natural landscape of the Wadden Sea. The author calls for a focus on better cooperation between the sectors of nature and culture, as both face important challenges. These include the protection of old grasslands and, in particular, climate change. The latter entails the necessity to implement renewable energy production in a way that allows natural and cultural values to remain protected and to develop measures for climate adaptation to allow the Wadden Sea to grow with the sea level. The author argues that more flexibility in finding new ways to deal with water would help to better adapt to the coming sea level rise in the cultural landscape. The extension of the Wadden Sea biosphere reserves with transition areas,
\end{abstract}

Egberts, Linde \& Schroor, Meindert (eds.), Waddenland Outstanding: The History, Landscape and Cultural Heritage of the Wadden Sea Region. Amsterdam: Amsterdam University Press, 2018 DOI: $10.5117 / 9789462986602 / \mathrm{CHO} 5$ 
as is being discussed and partly implemented in Germany, could be a good approach to improve the protection of cultural values in the Wadden Sea region.

Keywords: Wadden Sea, conservation, natural landscape, cultural landscape, climate adaptation

\section{Introduction}

There are not many other places in Western Europe, if any, that deserve the term 'natural landscape' as much as the Wadden Sea. And wherever one goes in the Wadden Sea, especially when moving further seawards from the dike, the landscape and nature all around usually look very natural. Most of what one can see there would have looked much the same 1,00o years ago. However, this chapter will argue that accepting the Wadden Sea as a natural landscape does not mean that there are not great cultural values as well deserving of acknowledgement and protection. There are thus good reasons to cooperate across the sectors.

\section{Why is the Wadden Sea predominantly a natural landscape?}

For our purposes, we define 'natural landscape' as a landscape that is predominantly formed by natural forces, the latter covering the whole range of geological to biological processes. Anthropogenic influences also exist in natural landscapes but play a minor role in actually forming their landscape and nature. As far as the Wadden Sea outside the dikes is concerned, this definition applies to almost the entire area (CWSS 2008 2012), such as the mudflats with abundant marine life, the tidal creeks and channels obviously being formed and continuously being changed by natural forces, as well as the salt marshes and dunes of which large parts have also been formed and continuously changed in a natural way. Then there are the islands or almost-islands, of which the large majority still have very natural parts, some of them even being completely natural.

This can also be expressed in extremes and numbers: the Wadden Sea is among the very few larger areas in Western Europe that remains mostly natural, having a size of about 10,000 square kilometres (with no well-defined border towards the sea, making it difficult to define an exact size). It consists of a very young and dynamic ecosystem. It has the largest 
Figure 5.1 A poster showing the East-Atlantic Flyway of waterbirds, with the Wadden Sea being the major hub right in the middle between most of the breeding areas and many of the wintering areas.

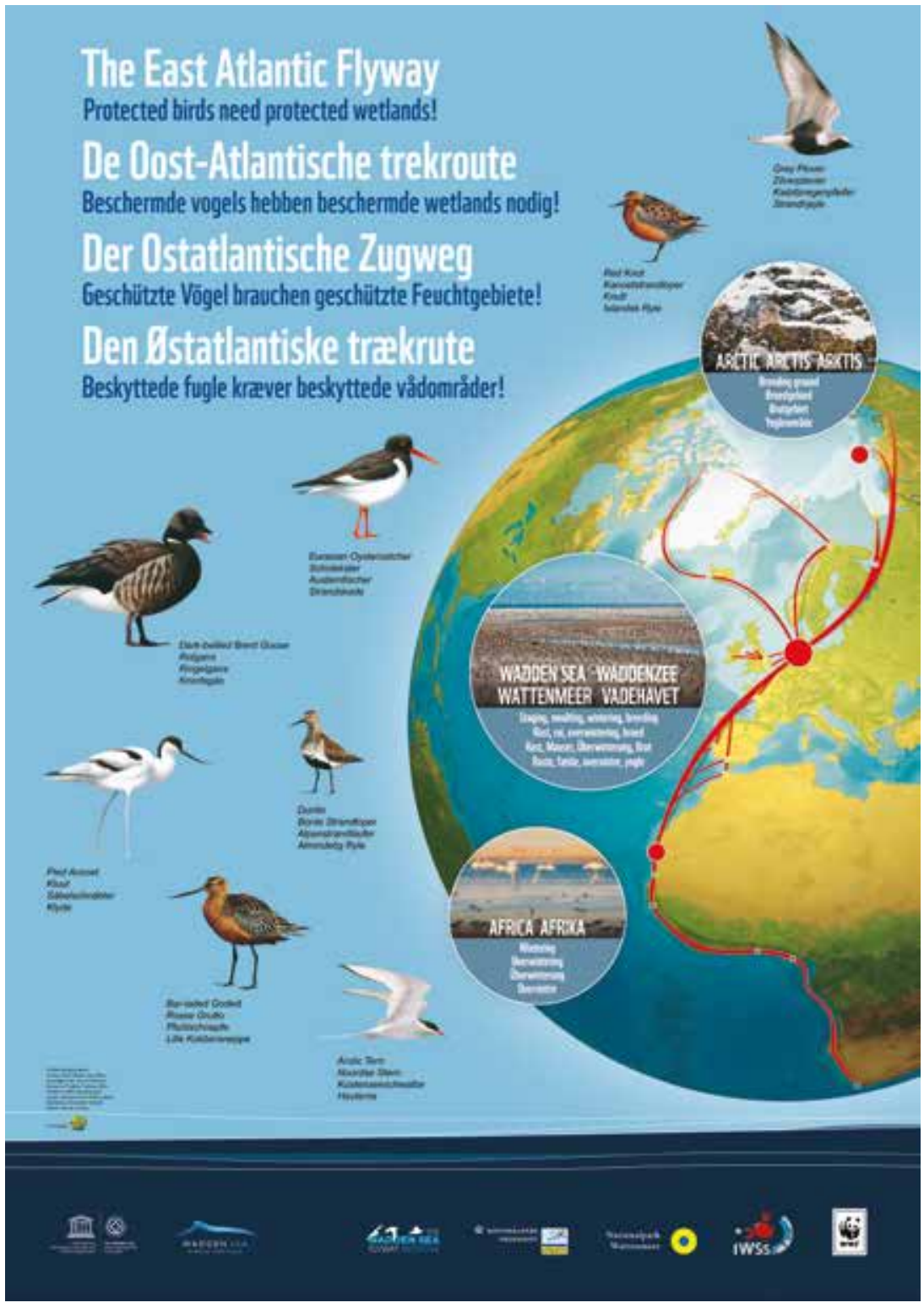

Courtesy of WWF Germany 
Figure 5.2 A natural landscape in the Wadden Sea.

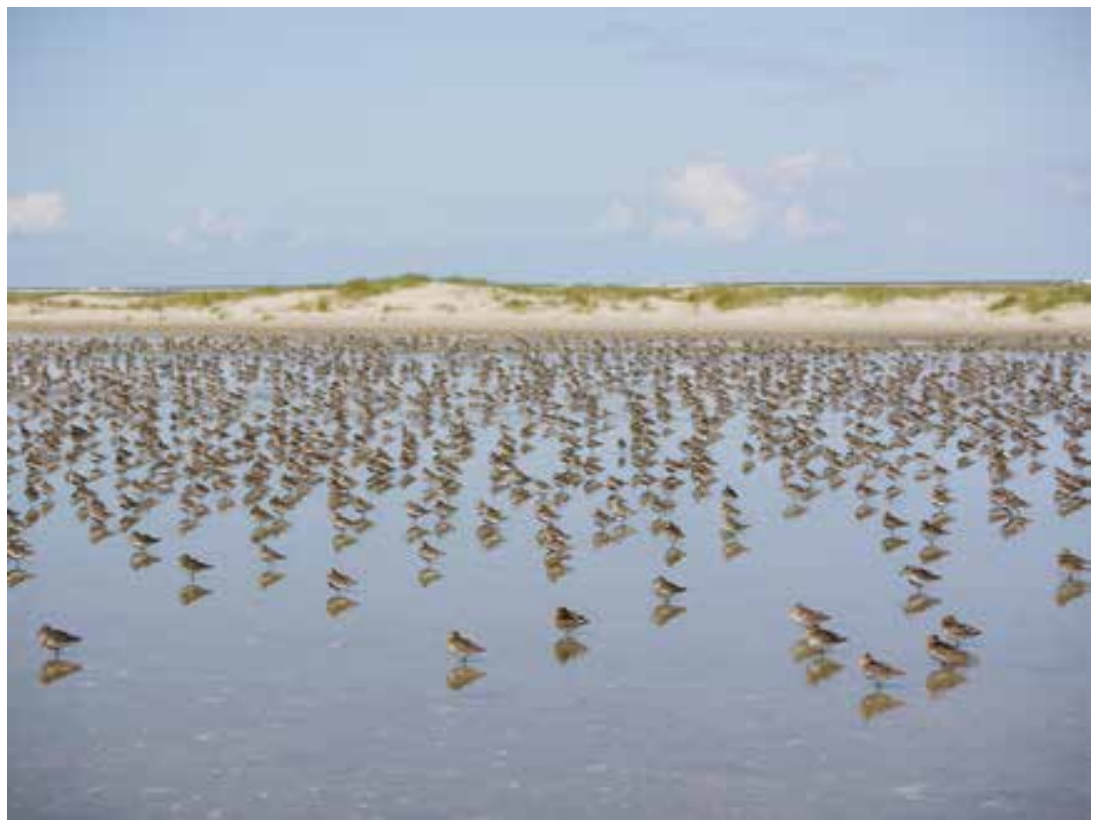

Photo by author

continuous intertidal area, with a size of about 4,500 square kilometres, and salt marshes of about 400 square kilometres. About 40,000 harbour seals and close to 5,500 grey seals live in the Wadden Sea and the adjacent North Sea. And more than 10 million waterbirds - about 9o percent of them originating from Arctic breeding grounds - depend on the Wadden Sea, which is an extremely important stepping stone on their flyway. The role of the Wadden Sea for the migration of birds, among the most amazing phenomena in the natural world, can hardly be overstated.

Obviously, there are also exceptions to the definition of natural landscape. At first glance, these may be more conspicuous to many than the actual natural landscape because these are the places people normally see first when they come to the Wadden Sea. Among them are anthropogenic structures in salt marshes and on islands, to mention just the most obvious. There are also historical settlement traces, usually inconspicuous. However, when considering the entire area, these cover minor parts of it. Even the fisheries, while influencing the habitat structure and species composition for almost the entire area, are not a predominant factor in constituting the landscape. To prevent any misunderstanding: this paper does not argue that the existing anthropogenic impacts are not highly problematic for the 
Figure 5.3 A cultural landscape in the Wadden Sea region, in this case old grassland with high natural values.

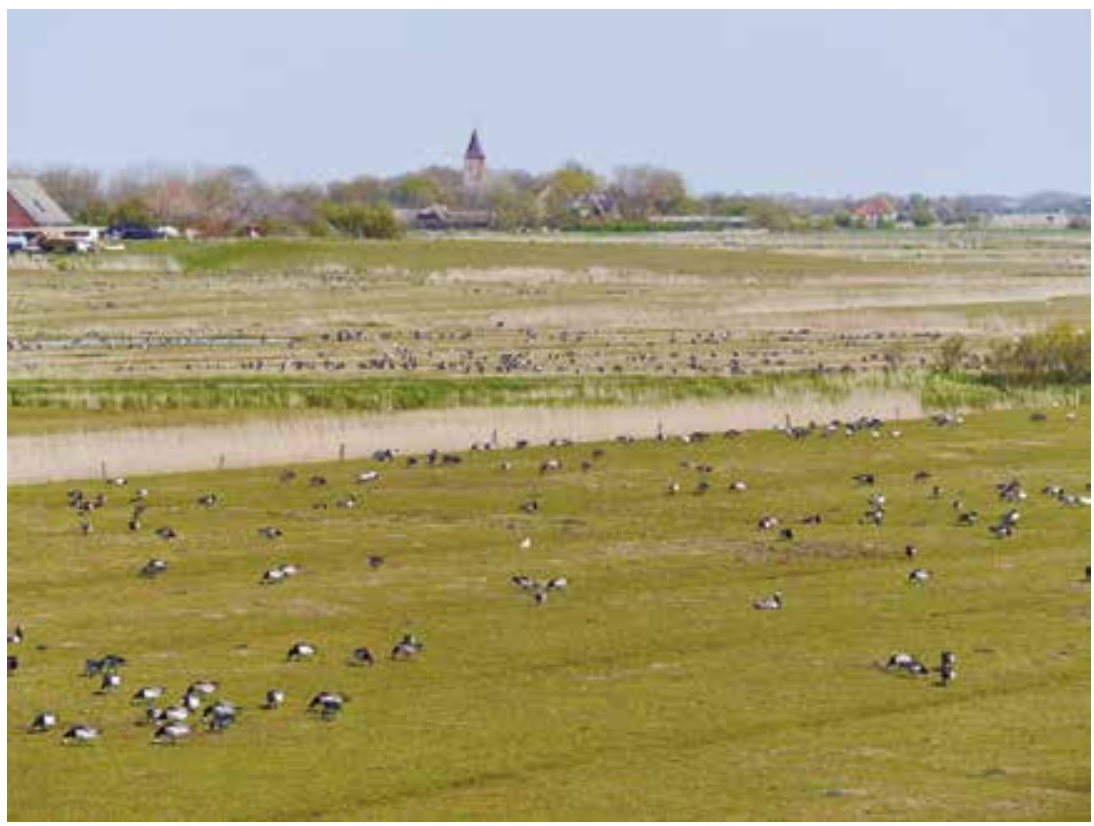

Photo by author

protection of the Wadden Sea and its species. What is argued is that they do not have the extent or impact to make the Wadden Sea a cultural landscape.

\section{Distinction between natural and cultural landscapes}

Where does the natural landscape end and where does the cultural landscape begin? All in all, there is a rather clear distinction between the largely natural landscape outside (i.e., seawards) of the dikes, which is the Wadden Sea in a more narrow sense, and the largely cultural landscape behind (landwards of) the dikes, which often is agriculturally used marshland. There are some exceptions to this rule, e.g. some quite natural landscapes on the land side of the dikes such as very wet polders, and some rather cultural landscapes on the seaside such as settlements and agricultural areas on islands. However, the overall pattern is the spatial segregation given by the dikes. This is not to say that such a segregation is necessarily a good one, as it unfortunately also interrupts ecological connections for species and habitats. But from the moment people started to build dikes, such a segregation became very 
difficult to avoid. The difference between natural and cultural landscapes on both sides of the dikes also finds its reflection in the wording. Outside the dikes, it is the 'Wadden Sea' in a more narrow sense. The term 'Wadden Sea region' can be used for the Wadden Sea plus the cultural landscapes behind the dike (more formally the Wadden Sea plus the adjacent provinces/ districts/municipalities; in essence, these are very often marshlands formerly deposited by the sea) plus the adjacent marine areas of the North Sea.

\section{Timely protection allowed the Wadden Sea to remain a natural landscape}

The Wadden Sea is an extremely valuable natural landscape of global importance, protected by the governments of the Netherlands, Germany and Denmark as well as jointly in the Trilateral Cooperation on the Protection of the Wadden Sea. It is also inscribed as a World Heritage Site - something to be proud of, to be sure, but not something that was easy to achieve.

The Wadden Sea was not always considered valuable nature. Until a few decades ago, it was considered by many to be land that had not yet been embanked and transformed into agricultural land. And it was the place where the danger caused by severe storm tides came from. Until the 1970s and 1980s, the number of embankments in the Wadden Sea only grew, and there were plans for even more (Wolff 1983). This trend came to an end as a result of the rise of the environmental movement, and discussions in society in all three Wadden Sea countries gave nature a much higher value than before. Thus, the reason for the remaining Wadden Sea still being a natural landscape today is that, historically, it has not been technically or economically possible to transform most of it into a cultural landscape, e.g. by embanking it. This is not because people in the past centuries loved the landscape and nature so much that they protected it. The reason may be much more that natural forces were so strong that large parts of the Wadden Sea could not be transformed into a cultural landscape before it was 'too late', i.e. before the protection of nature became an important value within our society.

A number of milestones describe the development of Wadden Sea conservation, which actually started long before the embankments were stopped. It was more than 100 years ago that some small islands were protected for their dense seabird colonies. In the decades that followed, the protected areas were enlarged, but still it was mainly species protection that guided the work of the early nature conservationists and not so much protection of the entire area where the species lived, i.e., their habitats. Habitat protection 
came more into focus in the 1970 and 1980s: the Trilateral Cooperation was established in 1978, and a Joint Declaration on protection was decided upon at a governmental conference in 1982. This was also around the time when the last large-scale embankments were constructed and when most of the Wadden Sea became protected in various ways, including Germany's designation of three national parks in the area between 1985 and 1990.

At the Trilateral Governmental Conference in Esbjerg in 1991, it was decided that: 'The Guiding Principle of the trilateral Wadden Sea policy is to achieve, as far as possible, a natural and sustainable ecosystem in which natural processes proceed in an undisturbed way' (CWSS 1991). This shows that there was already in the early 1990s a joint understanding that the Wadden Sea was a natural landscape. The guiding principle still is the most important guideline for Wadden Sea protection (Rösner 2010) and has been reaffirmed by the governments many times since 1991.

The decision on the Wadden Sea Plan in 1997 was another important milestone in Wadden Sea protection, but the most important turning point was when virtually the entire Dutch-German-Danish Wadden Sea was designated a UNESCO World Heritage Site. This occurred over the period 2009 to 2014. It is important to note that it was mainly the natural landscape outside the dikes - for example in Germany essentially the three Wadden Sea National Parks - that was nominated (CWSS 2008, 2012) and accepted by UNESCO as a natural site. The inscription was based on the statement of 'Outstanding Universal Value' consisting of three mandatory pillars:

- that the criteria to assess the global importance are fulfilled (natural geological and ecological processes and the necessity for global biodiversity),

- that the condition for integrity of the site is satisfied (large size, complete, representing all habitats/species/processes), and

- that there is adequate protection and management (national parks, nature reserves, Wadden Sea Plan, monitoring).

Given its inscription as a World Heritage Site, the protection of the Wadden Sea had to focus on preserving the Outstanding Universal Value. All three of its pillars must remain in place to meet the requirements. However, that also implies that there is much that still needs to be done (Green NGOs 2014).

All this does not mean that cultural landscapes in the Wadden Sea Region are not also highly relevant for nature - besides their cultural values. Important examples include the old grassland and the associated parceling structures with all its meadow birds, which is very much under pressure. Its loss would represent both a cultural loss and a loss of natural values. 
Figure 5.4 Edge of marshland on Hallig Hooge showing how with each flooding new sediment layers have been added, allowing the land to grow with the sea.

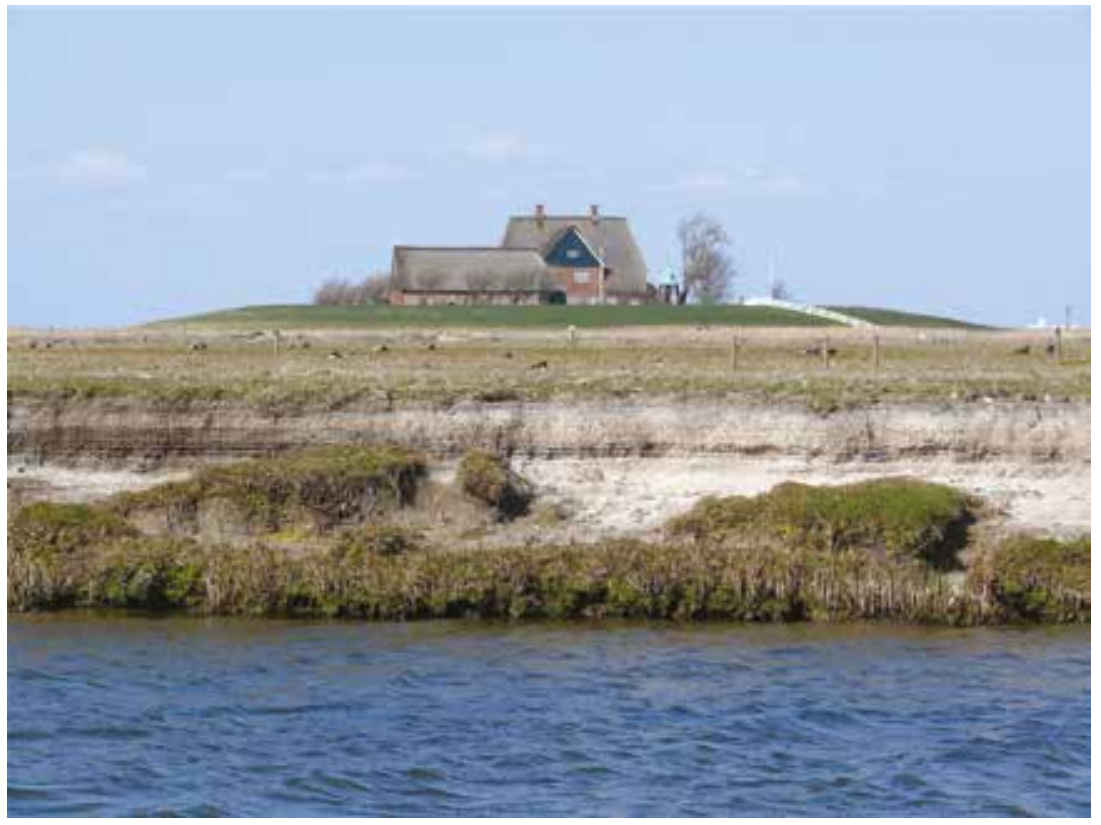

Photo by author

Joint challenges for preserving both the natural and cultural values of the Wadden Sea region

The case I am making for a better acceptance of the Wadden Sea as a natural landscape might be seen by some as not giving the appropriate value to the rich history and culture of the Wadden Sea region. This would be incorrect. As mentioned, some important natural values also depend on the protection of cultural landscapes that are situated mostly behind the dikes, as in the case of the old grassland. This is clearly a joint challenge, with the most success to be achieved if both natural and cultural values were to be protected. In the German part of the Wadden Sea, an interesting approach could be the extension of the Wadden Sea biosphere reserves with their transition areas, which covers those cultural landscapes behind the dikes where the local communities are in favour of this and where the existing cultural and natural values justify this. Following an initiative by the inhabitants, this concept was applied more than 10 years ago to the larger Halligen islands in the 
Schleswig-Holstein part of the Wadden Sea. The cultural and societal values in these remarkable places have in particular benefitted from this decision.

A fruitful cooperation may also be the best approach when it comes to climate change, the most important challenge facing the Wadden Sea and the Wadden Sea region. The most relevant impact for our coast may be a sharp sea level rise (CPSL 2001, 2005; Church et al. 2013). The longer the assumptions on the extent of the sea level rise vary, the more we will continue to see it as a future problem. However, it is now already clear that there will be a considerable increase, and it is well possible that by 2100 it will be more than one metre. Due to delayed effects, the sea level will continue to rise for a long time even if global climate protection policies are successfully implemented. Therefore, if we are to save the Wadden Sea against this human impact, adaptation measures are required. Such measures should focus on sediment management, which may help the Wadden Sea and its islands to grow with the sea while at the same time not becoming smaller (Helmer et al. 1996; CPSL 2010; Fröhlich \& Rösner 2015; MELUR 2015; Reise 2015; Hofstede 2015; Reise 2017). If carefully studied, piloted and implemented, such measures may also be compatible with the overall goal of Wadden Sea protection to allow natural processes to proceed as undisturbed as possible.

We must not forget that cultural values will also be impacted by the sea level rise, e.g. by erosion and disappearance and by the higher risks faced by those living in front of and behind the dikes. Already today, many of the areas behind the dikes are lower than the sea level, and this difference will only grow in the future. The traditional approach to making dikes higher and stronger will remain an important safety measure but may also not always be the best and only solution. An additional important approach for better protection of both cultural and natural values would be a greater flexibility in finding new ways to deal with water (Reise 2015). None of this will be an easy task, which is a good reason for those who work to protect natural values to join efforts with those who work to protect cultural values. However, no adaptation measure can in the longer term save the Wadden Sea if ambitious global climate policies are not implemented in time. This also means a clear responsibility for the Wadden Sea region to do its share. This intention has already been supported in the Sylt Declaration (CWSS 2010), declaring as a trilateral policy 'to work towards developing the Wadden Sea Region into a $\mathrm{CO}_{2}$-neutral area by 2030 or before'.

This means it must be accepted that the Wadden Sea region provide a significant amount of renewable energies and that the production and use of fossil energy sources such as oil and gas must be phased out quickly. 
Figure 5.5 New cultural landscape with the use of three different renewable energy sources. The surrounding land is intensively used by agriculture and has only very few nature values left, thus it is probably an appropriate choice of location.

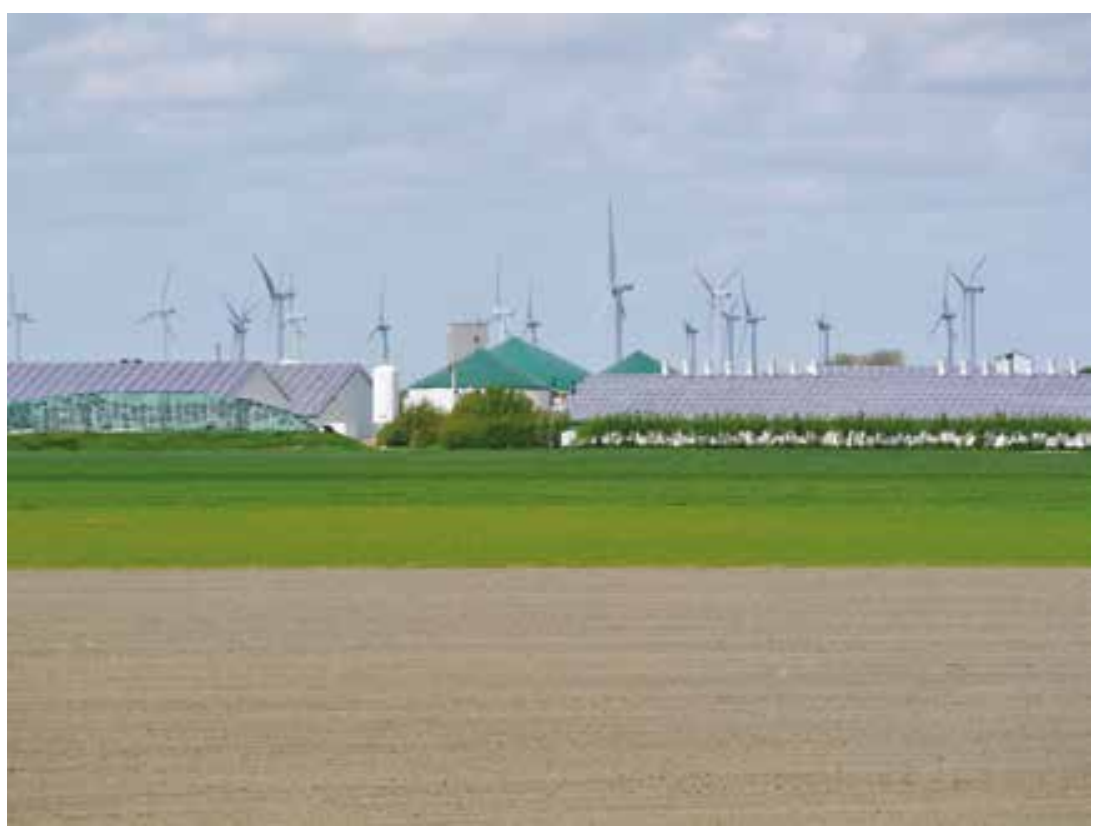

Photo by author

However, even the ambitious goal of achieving climate neutrality within the region will not be enough, because energy must also be provided for other parts of our countries that have naturally much less wind to use for energy production. As can be seen in many (but not all) practical cases in the region, it is possible to set up enough renewables while at the same time keeping natural and cultural values well-protected. However, these cases also show that compromises must be made and underscore my argument that cross-sectoral cooperation would be invaluable in finding the best suitable locations for renewable energy production with the least potential to damage the landscape as well as nature and cultural values.

\section{Conclusions}

We can and should be proud of what has been achieved so far in the Wadden Sea region — not only for the region's unique nature but also for 
our unique cultural values. Both sectors should improve their cooperation, as the Wadden Sea and Waddenland are part of one whole that we all need to take care of. For this, we have to create and support identity, cooperation, credible sustainable development and credible protection. The Waddenland approach may well contribute to this, if it comprises both the Wadden Sea in a narrow sense and the adjacent and embedded cultural landscapes, and if the coexistence of the two as wilderness/natural landscape on one side of the dike and cultural landscape on the other side is fully accepted. The many natural links between the two - including the fact that much of the cultural landscape has developed thanks to the sedimentation under marine conditions - should not be forgotten. A very important approach for better protection of natural and cultural values would be a greater degree of flexibility in finding new ways to deal with sediment and water to better adapt to the rise in the sea level, both seawards and landwards of the dikes. And an interesting approach in the German part of the Wadden Sea, still in its starting phase after good experiences on the Halligen, is to offer a sort of protective umbrella for culturally valuable parts of the landscape via the transition area of biosphere reserves.

\section{Acknowledgments}

Thanks are due to Barbara Ganter and Meindert Schroor for their constructive comments.

\section{References}

Church, J.A., Clark, P.U., Cazenave, A., Gregory, J.M., Jevrejeva, S., Levermann, A., Merrifield, M.A., Milne, G.A., Nerem, R.S., Nunn, P.D., Payne, A.J., Pfeffer, W.T., Stammer, D. and Unnikrishnan, A.S. (2013). Sea Level Change. In: Climate Change 2013: The Physical Science Basis. Contribution of Working Group I to the Fifth Assessment Report of the Intergovernmental Panel on Climate Change. Cambridge: Cambridge University Press.

Common Wadden Sea Secretariat, Trilateral Working Group on Coastal Protection and Sea Level Rise (CPSL) (2001). Coastal Protection and Sea Level Rise. Final Report of the Trilateral Working Group on Coastal Protection and Sea Level Rise. Wadden Sea Ecosystem 13. Retrieved from www.waddensea-secretariat.org/ sites/default/files/downloads/cpsl-report.pdf. 
Common Wadden Sea Secretariat, Trilateral Working Group on Coastal Protection and Sea Level Rise (CPSL) (2005). Coastal Protection and Sea Level Rise - Solutions for sustainable coastal protection in the Wadden Sea region. Wadden Sea Ecosystem 21. Retrieved from www.waddensea-secretariat.org/sites/default/ files/downloads/cpsl-ii-2005.pdf.

Common Wadden Sea Secretariat, Trilateral Working Group on Coastal Protection and Sea Level Rise (CPSL) (2010). CPSL Third Report - The role of spatial planning and sediment in coastal risk management. Wadden Sea Ecosystem 28. Retrieved from www.waddensea-secretariat.org/sites/default/files/downloads/ cpsl_third_report.pdf.

CWSS (1991, November 13). Ministerial Declaration of the 6th Trilateral Governmental Conference on the Protection of the Wadden Sea, Esbjerg. Wilhelmshaven.

CWSS (2008). Nomination of the Dutch-German Wadden Sea as World Heritage Site. Retrieved from www.waddensea-secretariat.org/sites/default/files/downloads/ whs-final-dossiero8-01-16.pdf.

CWSS (2010, March 8). Ministerial Council Declaration of the 11th Trilateral Governmental Conference on the Protection of the Wadden Sea, Westerland/Sylt. Retrieved from www.waddensea-secretariat.org/sites/default/files/downloads/ sylt-md-complete-final-11-02-08-web.pdf.

CWSS (2012, December 21). The Wadden Sea, Germany and Netherlands (N1314) Extension Denmark and Germany. Retrieved from www.waddensea-secretariat. org/sites/default/files/downloads/whn-denmark-niedersachsen21-12-12_lq.pdf.

Fröhlich, J. and Rösner, H.U. (2015). Klimaanpassung an weichen Küsten - Fallbeispiele aus Europa und den USA für das schleswig-holsteinische Wattenmeer. Retrieved from wwf.de/watt/klianpglobal.

Green NGOs of the Wadden Sea Region (2014, August 28). The 2014 Call for Action for the Wadden Sea. Presented at the Wadden Sea Day. Retrieved from www.wwf.de/ fileadmin/fm-wwf/Publikationen-PDF/The_2014_Call_for_Action_for_the_Wadden_Sea.pdf.

Helmer, W., Vellinga, P., Litjens, G., Goosen, H., Ruijgrok, E. and Overmars, W. (1996). Growing with the Sea - Creating a Resilient Coastline. Retrieved from www.wwf.de/fileadmin/fm-wwf/Publikationen-PDF/WWF-NL_1996_Growing_with_the_Sea.pdf.

Hofstede, J.L.A. (2015). Theoretical considerations on how Wadden Sea tidal basins may react to accelerated sea level rise. Zeitschrift für Geomorphologie 59, 377-391. MELUR (Ministerium für Energiewende, Landwirtschaft, Umwelt und ländliche Räume des Landes Schleswig-Holstein) (2015). Strategie für das Wattenmeer 2100. Retrieved from http://www.schleswig-holstein.de/DE/ Fachinhalte/N/nationalpark_wattenmeer/bericht_strategie_wattenmeer210o. pdf?_blob=publicationFile\&v=4. 
Reise, K. (ed.) (2015). Kurswechsel Küste - Was tun, wenn die Nordsee steigt? HanseThesen zur Klimaanpassung. Wachholtz-Verlag - Murmann Publishers, Kiel/ Hamburg.

Reise, K. (2017). Facing the Third Dimension in Coastal Flatlands. Global Sea Level Rise and the Need for Coastal Transformations. GAIA 26/2: 89-93. Retrieved from https://epic.awi.de/44953/1/GAIA2_2017_089_093_Reise.pdf.

Rösner, H.U. (2010). The Guiding Principle for the Wadden Sea: Advantages of a dynamic approach in a changing world. Wadden Sea Ecosystem 26: 23-28. Retrieved from www.waddensea-secretariat.org/sites/default/files/downloads/ wse-no-26-procceedings-20o9.pdf.

Wolff, W.J. (ed.) (1983). Ecology of the Wadden Sea. Balkema, Rotterdam.

Zukunft Dockkoog - Gemeinsam für Husum mehr erreichen, Bericht der Projektgruppe Dockkoog 2015/16 (2016). Retrieved from www.wwf.de/fileadmin/ fm-wwf/Publikationen-PDF/Zukunft-Dockkoog-Bericht-der-ProjektgruppeDockkoog-2015-2016.pdf.

\section{About the author}

Hans-Ulrich Rösner has been working for the protection of the Wadden Sea since 1984. As a biologist and ornithologist, he began working for the Schutzstation Wattenmeer on the island of Pellworm, and since late 1985 he has worked for the global nature conservation organisation World Wildlife Fund (WWF), initially on migratory bird research and monitoring. He is now head of the Wadden Sea office of WWF based in Husum, focusing with his team on issues such as fisheries, tourism, energy, shipping, coastal defence, nature restoration and climate adaptation but also on public information and education. He has supported the development of the national parks in the German part of the Wadden Sea as well as the progress in trilateral cooperation. On behalf of the WWF and the Green NGO's Wadden Sea Team, he is also serving as an advisor to the trilateral Wadden Sea Board. 
